\title{
The Extent of the Application of Community Service Order as an Alternative Punishment in Malaysia
}

\author{
Anita Abdul Rahim (Dr. PHD), \\ Lecturer in the Faculty of Law, National University of Malaysia
}

Tengku Noor Azira Tengku Zainudin (Dr. PHD)

Lecturer in the Faculty of Law, National University of Malaysia

Mohamad Afiq Taqiudin Roslan

Student/Research Assistant, Faculty of Law, National University of Malaysia

\section{Doi:10.5901/mjss.2013.v4n10p154}

\section{Abstract}

The criminal justice system provides a range of punishment to be meted out to criminal offenders. The types of punishment include custodial and non-custodial sentences. Custodial sentence refers mainly to imprisonment of the offenders. On the other hand, there are several types of noncustodial sentence such as fine, probation and bond of good behaviour. Recently it can be seen that a new kind of non-custodial sentence, that is community service order has gained acceptance by the courts of law in several criminal jurisdictions in the world such as the United Kingdom and the United States of America. As a developing country, Malaysia must be proactive in keeping abreast of this legal development. Therefore it is important to identify whether in Malaysia there exists provisions of law that allow for the application of community service order as an alternative punishment. This paper aims at discussing the provisions of law pertaining to community service order and the extent of its applicability in criminal cases in Malaysia. For the purpose of this paper, the writers adopted a qualitative method, focusing on statutory analysis in order to reach the desired objective.

Keywords: Community service - alternative punishment - crimes - offenders

\section{Introduction}

It is an undeniable fact that prison has an important role to play in protecting the community against the most dangerous offenders and in punishing the most serious crimes. On the other hand, imprisonment as a type of custodial sentence can also harm the chances of the offenders' opportunities to amend and fulfil their potential as citizens and to contribute to civil society and democratic life. In this context, it is also important to find effective alternatives to prison for offenders who can be safely punished in the community. This is considered a current development in most of the criminal justice systems, including Malaysia. In Malaysia, community service is not always used by the judges as alternatives to imprisonment. This type of sentence was first introduced in the Malaysian Criminal Procedure Code, under section 293, a provision pertaining to juvenile offenders.

According to Martin Wasik (2001), community sentence is one of the available sentencing options, appropriate in cases where the offender has committed an offence of an intermediate degree of seriousness. The judges impose the order in a view that the nature of the offence is not such as to require custody, but it does require something more than the mild penalty of a bind over or a discharge.

Under the English law, not all sentences that are by nature non-custodial are 'community service sentence'. 'Community sentence' under the English law is defined in Powers of Criminal Courts (Sentencing) Act 2000 under section 33(1) so as to encompass the community rehabilitation order (formerly probation order), the community punishment order (formerly community service order), the community punishment and rehabilitation order (formerly combination order), the curfew order, the attendance centre order, the supervision order, the exclusion order, the drug treatment and testing order, the drug abstinence order and the action plan order. 
As for the Malaysian law, we do not have a specific act pertaining to community service order as a sentence. However, there are few provisions in the Malaysian legislations that give inference as to the application of this type of sentence. Those provisions of law are highlighted in this paper to identify the extent of its application under the Malaysian criminal jurisdiction.

\section{What is for community service order?}

Community service order is an order meted out by the court that requires an offender to perform services or duties for a specified period of time without any wages for the welfare agency and society. There are usually five aspects to this order: the court giving the order, the type of the order, the period of service, consideration from the services rendered, and the party served (Claster, 1992). This order is also defined as a non-custodial punishment as it will not involve imprisonment or considered as an alternative to imprisonment.(McLaughlin \& Munchie, 2006). Some refer community service as community corrections which is defined as a nonincarcerative sanction in which offenders serve all or a portion of their sentence in the community. (Leanne Fiftal Alarid, 2013)

As a whole community service order provides opportunities for offenders to learn job skills, get vocational training and other important life skills. At the same time, it repairs the harm caused by their actions while making contributions to the communities in which they live. Thus it is submitted that community service order is a two way street; that is the active involvement of both offenders and the community.

\section{How community service addresses sentencing goals?}

Community service addresses the traditional sentencing goals of punishment, reparation, restitution and rehabilitation. By serving the community, community service order adds a punitive measure to probation because it is a special condition of probation or supervised release. It restricts offender's personal liberty and requires them to forfeit their leisure time. In achieving reparation, community service allows offenders atone or 'make the victim whole' in a constructive way. Besides, community service may be regarded as a substitute for financial compensation to individual victims or a form of symbolic restitution when the community is the victim. This will achieve the aim of restitution. And the most important characteristics of community service is rehabilitation whereby this kind of order fosters a sense of social responsibility in offenders and allows them to improve their self-image through serving the community. It also instils a work ethic and helps offenders develop interest and skills.

Community service is premised upon the belief that offenders and also victims of crime have rights deserving of protection. Apart from that, human beings are capable of change, that is one of the reasons why a commitment to the reintegration of the offender into the community is very essential.( Leanne Fiftal Alarid, 2013)

\section{The Malaysian legal basis for community service: An Overview}

It is to be noted that the legal basis for community service order is provided by the legal and institutional framework. Nevertheless for the sake of this paper, only the legal framework is analysed to look at the extent of its application in Malaysia The implementation of community service order in Malaysia is provided in a number of laws; which set up the mechanism and the operative facilities that cater for the implementation of the order. The relevant statutes are Criminal Procedure Code, Child Act 2001, Offenders Compulsory Attendance Act 1954 and Drug Dependants (Treatment and Rehabilitation) Act 1983 (Act 283).

\subsection{Criminal Procedure Code (Act 593)}

This act is a criminal procedural act in Malaysia. Community service order is defined in section 293 regarding the application of punishment for young offenders. Young offender is defined in section 2 of the Criminal Procedure Code as a person of 18 years and above but below the age of 21. The order has been incorporated in the provision through Criminal Procedure Code Act (Amendment) 2006 (Act 1274) to replace para (d) with the following paragraph:

(e) 
(i) to make an order requiring the offender to perform community service, not exceeding 240 hours in aggregate of such nature and at such time and place and subject to such conditions as may be specified by the court;

(ii) in this paragraph "community service" means any work, service or course of instruction for the betterment of the public at large and includes, any work performed which involves payment to the prison or local authority; and

(iii) the community service under this paragraph shall be under the Minister charged with the responsibility for women, family and community. (The Ministry of Development of Women, Family and Society has been given the responsibility to promulgate and implement the community service programmes.)

It should be observed that community service order can only be imposed on a child offender between the ages of 18 to 21. Therefore a child aged below 18 will not be entitled to this type of punishment. In line with this provision, the Malaysian Ministry of Women, Family and Society Ministry has established a special unit for the order of community service with three objectives, namely;

i. $\quad$ punishment; by giving the child offender a responsibility to be discharged based on their needs.

ii. rehabilitation; by stimulating a social responsibility and making community service programmes as useful experience to the child offenders

iii. reparation; by giving rooms or opportunities to child offenders to be reformed and rehabilitated and offering benefits to the society.

\subsection{Child Act 2001 (Act 611)}

This act is only applicable for those below the age of 18 years. The 611 Act defines child as a person under the age of eighteen years and in relation to criminal proceedings, child means a person who has attained the age of criminal responsibility as prescribed in section 82 of the Penal Code.

As to date there is no specific provision on community service order in the Child Act 2001. Nevertheless if sections 83 and 91 on the types of punishment are read together, the application of community service order can be inferred .

Section 91 of the Child Act 2001 reads:

Powers of Court For Children on proof of offence

(1) If a Court for Children is satisfied that an offence has been proved the court shall, in addition to any other powers exercisable by virtue of this act, have power to-

(a) admonish and discharge the child

(b) discharge the child upon his executing a bond to be of good behaviour and to comply with such conditions as may be imposed by the court;

(c) order the child to be placed in the care of a relative or other fit and proper person -

i. $\quad$ for such period to be specified by the court and

ii. $\quad$ with such conditions as may be imposed by the court;

(d) order the child to pay a fine, compensation or costs;

(e) make a probation order under section 98;

(f) order the child to be sent to an approved school or a Henry Gurney School

(g) order the child if a male, to be whipped with not more than ten strokes of a light cane -

i. within the court premises

ii. in the presence, if he desires to be present, of the parent or guardian of the child.

(h) impose on a child, if he is aged fourteen years and above and the offence is punishable with imprisonment and subject to subsection 96(2) any term of imprisonment which could be awarded by a Session Court.

The relevant paragraphs concerning on community service are Para (a), (b), (c), and (e) where, when one of these types of punishments is imposed on the child offender, the elements of community service concept might be applied. For example, when offenders are put under probation, they are released into the community with the proviso that they must meet certain conditions or risk further punishment. The conditions imposed generally erquire that offenders are under the supervision of a probation officer with whom he is expected to meet regularly. Nevertheless, since this provision of law is silent as to the additional punishment of community service, the extent of its application is very vague and unclear for those offenders below the age of 18 under this act.

Section 83(3) also provides :- 
When an offence is committed by a child but a charge in respect of that offence is made against the child after he has attained the age of eighteen years, the charge shall be heard by a court other than a Court For Children and that other Court may exercise the power mentioned in paragraph (2)(a), (b) or (c).

Section 83(2) provides:-

When a child is charged with an offence before a Court For Children and during the pendency of the case he attains the age of eighteen years the Court For Children shall, notwithstanding any provisions of this Act, continue to hear the charge against the child and may -

(a) exercise the power under section 76

(b) exercise the power under paragraph 91(1) (a), (b), (c), (d) or (g); or

(c) if the offence is punishable with imprisonment, impose any term of imprisonment which could be awarded by a Sessions Court.

For cases where a child has attained the age of 18 at the time the charge is made, based on this section, it can be inferred that an order for community service can be made by the court by virtue of sub section 2(b). The court still retains the power to make such order even in cases where the child offender has attained the age of eighteen.

As a conclusion, eventhough it can be inferred that an order of community service can be made based on the above mentioned provisions in the Child Act 2001, however it is suggested that to give clarity to this area, a specific provision giving the court power to order community service must be incorporated.

\subsection{Offenders Compulsory Attendance Act 1954 (Act 461)}

This legal statute has long been in existence in Malaysia. The preamble of this act states:

An Act to provide for the performance in certain circumstances, of compulsory work by offenders convicted of certain offences and liable to be sentenced to imprisonment or by persons liable to be committed to prison for failure to pay a fine or debt, in lieu of being so sentenced or committed; and for purposes connected therewith.

"Compulsory work" has been defined in this Act as any labour, task, work or course of instruction ordered by the Compulsory Attendance Centre Officer to be undertaken by the offender. (Locations or centres gazetted for offenders to report attendance were as directed by the Home Minister on $4^{\text {th }}$ July 2010 through the gazette [KDN PDP (S): 03/22/3(2)]

With this order, the offender has to attend daily at a centre to be specified in the order and to undertake compulsory work for a period not exceeding 3 months and for such hours, not exceeding 4 hours as may be specified in such order.

Where a person has been convicted of an offence for which he is liable to be sentenced to imprisonment or is liable to committed to prison for failure to pay a fine or debt, and the court is of the opinion that such person would have been adequately punished by a sentence of imprisonment for a period not exceeding 3 months, and having regard to the character of such person, the nature and seriousness of the offence or the circumstances of such person's failure to pay and all the other circumstances of the case, it is inexpedient to commit him, the court may in lieu of such sentence or committal make a compulsory attendance order. This has been provided in section 5 .

The obligations of offenders under a compulsory attendance order have been set out in section 6 of the act. It reads:-

(1) Subject to the provisions of any rules made under this act and to the terms of the compulsory attendance order, an offender shall during the continuance in force of such order report daily at such time and place as, having regard to the offender's circumstances, the compulsory attendance officer may specify.

(2) An offender shall each day undertake such compulsory work as may be ordered by the compulsory attendance centre officer which shall be such work as can, in the opinion of that officer, be completed by the offender having regard to his physical capacity during the number of hours specified in the compulsory attendance order.

(3) If an offender is gainfully occupied in employment, the time at which he is ordered to report daily under sub section (1) shall be such as not to interfere with such employment.

The accused is required to secure bond either with or without guarantor. This is to ensure that the accused will obey the compulsory attendance order. Before an order is imposed, the court must explain in a language understood by the accused the percussions of not obeying the order and the court cannot make any compulsory attendance order if the accused refuses to obey the order that is going to be imposed.

By virtue of Act 461, compulsory attendance order is one of the additional punishments to imprisonment imposed by the court without affecting the life of the offender in society. The order is under the management and administration of 
Malaysian Prison Department. By this order, the court will direct the offender to report himself every day at the compulsory attendance centre. This is in order for the offender to carry out duties or services for the benefit of the society and also to undergo rehabilitative programme not more than four hours per day. The offender will be supervised by an officer at the compulsory attendance centre as specified in the whole country.

Minor offences offenders are given an option to perform community service duties which will not affect their existing jobs. Examples of duties or services under the compulsory attendance order in Act 461 which are presumed to be similar to community service order are as follows:

1. to work with workers from local government or local councils to clean the town surroundings etc

2. to work at hospitals or public health centres in order to assist the elderly sick patients

3. to work at recreational parks, playgrounds and clean public facilities

4. to work at places of worship, welfare houses and orphanage

5. to attend motivational classes, lectures and career talk

6. to attend short term courses at training centres and other sponsored courses at government training centers

7. other works or services considered appropriate by the compulsory attendance officer in the respective districts.

\subsection{Drug Dependants (Treatment and Rehabilitation) Act 1983 (Act 283)}

This is another non-custodial sentencing options in Malaysia. It is not directly considered as a community service order, but the programmes established by the rehabilitation centres may indirectly involve the community. Under this particular act, the government has established rehabilitation centres for the residence, treatment and rehabilitation of drug dependants. Instead of being processed through the criminal justice system, a magistrate may order a proven drug dependant to undergo treatment and rehabilitation at a specified rehabilitation centre for a period of two years and thereafter to undergo supervision by a Rehabilitation Officer or any police officer at the place specified in the order for a further period of two years.

Section 6(1) of the Act states:-

Where a person who has undergone the tests referred to in section 3 or 4 , in consequence of such tests, is certified by a government medical officer or a registered medical practitioner to be a drug dependant, the officer shall produce him, or cause him to appear before a Magistrate, and the Magistrate shall upon the recommendation of a Rehabilitation Officer and after giving such person an opportunity to make representations -

(a) order such person to undergo treatment and rehabilitation at a Rehabilitation Centre specified in the order for a period of two years and thereafter to undergo supervision by an officer at the place specified in the order for a period of two years, or

(b) order such person to undergo supervision by an officer at the place specified in the order for a period of not less than two and not more than three years.

The act also provides the conditions for an order of supervision that shall be imposed on a person in Section 6(2). The conditions are:-

1. The person must reside in a state or Federal Territory or any area as specified in the order.

2. The person must not leave the area where he resides without the written permission of the Director General

3. At the time specified in the order, the person shall report at the nearest police station or for a member of the armed forces at the place specified by an officer

4. The person shall not consume, use or possess any dangerous drugs

5. The person shall undergo such tests at such time and place as may be ordered by an officer

6. The person shall undergo any programme for the rehabilitation of drug dependants heild by the government.

Therefore it can be concluded that community service as a non-custodial punishment is not totally alien to the Malaysian criminal justice system. What is needed is only a nudge to the right direction so as to enable this type of order to play its appropriate role.

\section{Conclusion}

It is submitted that community service is a fairly new concept in the Malaysian criminal justice system in Malaysia. However with the incorporation of community service order for juvenile offenders under section 293 of the Malaysian Criminal Procedure Code, it shows that our jurisdiction begins to recognise the need of a new approach of sentencing 
offenders. The authors agree with suggestions proposed by Mark S Umbreit (1981) that community service must be viewed as a criminal punishment. Unless it is viewed as a legitimate criminal punishment in and of itself, it will not be taken seriously by judges as a replacement for other forms of punishment.

Thus, in order to ensure the success and effectiveness of the community service order, the government should provide clearer and specific law pertaining to this type of sentence, therefore it will give clarity of its implementation, especially to what types of offences and offenders it shall be imposed. Besides, the offenders must be made aware of the purpose and intended outcomes of their community service activities. The court staff and judges also, at the same time must understand what is at stake and understand the reasoning behind the idea of imposing community service. If the aim is really to give the offenders help and support in order to facilitate his adjustment to society, their real needs should be determined. In achieving this, a research should be undertaken or conducted to investigate the needs of the offenders who fall within the ambit of the community service order.

\section{References}

Caputo, G.A. (2004). Intermediate Sanctions in Corrections, USA : University of North Texas Press.

Cluster, D.S. (1992). Bad Guys and Good Guys: Moral Polarization and Crime, Westport City: Greenwood Press.

G R Markham. (1981). A Community Service For Elderly Offenders. 54 Police J, 235- 240 .

Gill Mclvor . (2010). Community Service in Belgium, the Netherlands, Scotland and Spain: A Comparative Perspective. European Journal of Probation 2(1), $82-98$.

Leanne Fiftal Alarid. (2013). Community - Based Corrections, Ninth Ed, USA : Wadsworth Cengage Learning.

Mark S Umbreit. (1981). Community Service Sentencing : Jail Alternative or Added Sanction, HeinOnline, 45 (Fed. Probation 74), 13 20.

Martin Wasik, (2001). Emmins on Sentencing $4^{\text {th }}$ Ed, UK : Blackstone Press.

Mc Laughlin, E \& Munchie,J. (2006). The SAGE Dictionary of Criminology, London : SAGE.

Miranda Boone. (2010). Only for minor offences: Community Service in the Netherlands. European Journal of Probation,2(1)), 22-40.

Ray Stortini. (1979). Community Service Order, 21 Criminal Law Quarterly, 503- 508.

Ulla V. Bondeson. (2002). Alternatives to Imprisonment: Intentions and Reality, USA \& London : New Brunswick \& London Publisher. 